\title{
Community Empowerment to Improve the Village Economy through the Utilization of Tea Leaves in Bahbutong Village, Simalungun Regency
}

\author{
Siti Hajara), Fiqih Hasan Ashary, Aryo Hermawan, Nurkhay Rani, \\ Indri Monika, and Faiza Stevani
}

\author{
Universitas Muhammadiyah Sumatera Utara, Medan, Indonesia \\ a)CorrespondingAuthor: sitihajar@umsu.ac.id
}

\begin{abstract}
The community empowerment program is an activity that aims to increase the understanding and knowledge of the community in utilizing the existing potential. The level of understanding and knowledge of the community in Bahbutong Village is still limited in carrying out activities to utilize the potential of the village, this is related to the not optimal community empowerment efforts carried out. One of the potentials that can be pursued and reprocessed so as to get direct benefits that can be felt by the village community is tea leaves. So far, people only know that tea leaves are only for food and drink, so they have not been able to make a big contribution to the village economy. Utilization of tea leaves in Bahbutong Village can be an effort to improve the village economy through community empowerment activities carried out by the village government. The tea leaves in question are unused leaves or leftovers from tea plantations in Bahbutong Village. The method used in this research is the participatory rural appraisal (PRA) method. The results obtained in this study are new innovations in the use of tea leaves, namely the manufacture of tea aromatherapy candles that can provide relaxation for breathing and can also optimize community empowerment programs so that the village economy can increase.
\end{abstract}

Keywords: empowerment, community, village, innovation, tea leaves

\section{INTRODUCTION}

The enactment act 6 of 2014 concerning Villages is an opportunity and challenge for the government in building and developing villages as well as empowering the community as an effort to achieve maximum welfare. The community empowerment program which is alleged to be an effort or action to improve the ability and knowledge of the community in all sectors of life is a big challenge for the government to create a prosperous society.

The opportunities that exist in the implementation of the Village Law are opportunities for villages to be more advanced through community empowerment programs by utilizing the potential that exists in the village. Utilization of village potential as the main capital in village development also provides added value for increasing public understanding so as to produce ideas or ideas that can become breakthroughs or new innovations in supporting the village economy. Nahruddin (2014), that community empowerment is the key to help increase people's income in developing resources and becoming business opportunities.

Community empowerment implemented is a priority development program in implementing Law Number 6 of 2014 concerning Villages, which aims to strengthen communities as the key to successful village development in all sectors. Hamid (2018), that in implementing community empowerment programs, good governance is needed related to participatory planning so that it can directly identify problems found in the village community. Then, Mardikanto and Soebiato (2012), suggest that empowerment as a process is a series of activities that can strengthen abilities and produce excellence so that they can obtain opportunities and opportunities to improve the quality of life both as a group and individually. Thus, community empowerment is a planned process in improving the quality of life through the ability to participate in obtaining opportunities so that they can access resources that can support the fulfillment of needs.

However, in the implementation of village development programs through community empowerment activities carried out by the village government of Bahbutong, there are obstacles 
that ultimately affect the success of village development. The problems are 1) lack of community involvement in village development programs; 2) the reduced demand for tea leaf production from the Bahbutong plantation so that it has an impact on the economy of the community around the plantation, namely Bahbutong Village. Thus, regarding the community empowerment program carried out in Bahbutong Village by innovating tea leaves into aromatherapy candles so that they can support efforts to improve the village economy and prosper the community through processing unused tea leaves (harvest remnants) from PTPN IV Bahbutong. The problems described above, the village government is trying to overcome the solution by improving the community's economy through the use of tea leaves, so that no more tea plants are wasted, but provide benefits for people's lives.

\section{METHOD}

The method used in community empowerment to improve the village economy through the use of tea leaves in Bahbutong Village is the Participatory Rural Appraisal (PRA) method, Riyadi and Bratakusumah (2005) which means that PRA is a method of learning about conditions and rural life from, with and by the village community itself and aims to produce program designs that are more in line with community needs. While Adimihardja, K and H.H (2003) that this method aims to accommodate and involve the community in designing actions that include planning, monitoring and evaluating programs or policies that have an impact or impact on life.

\section{RESULTS}

The village always collides with economic problems, which are related to limited knowledge and understanding in developing the potential that exists in the village, including what happened in Bahbutong Village. This village is a village where the majority of the people are plantation farm laborers, where the community only relies on the salary given by PTPN IV (Tea Plantation), and also influences the mindset of the community to be able to develop and be independent. However, since 2019 there has been a decline in production which eventually led to the Bahbutong tea plantation experiencing financial economic crisis problems. This is due to the fact that tea commodity products in Simalungun Regency are unable to compete with tea commodity products from other countries, such as China, India and Vietnam. The quality of PTPN IV tea production is also less competitive with the international market, this happens as a result of most of the tea plants in Simalungun are tea plants that are quite old, most of the tea plants in Simalungun are still old Dutch heritage plants, because The quality of tea commodities from Simalungun is difficult to compete in the international market.

The occurrence of financial economic problems at PTPN IV made some people experience a financial crisis, this is because small tea farmers are more oriented to the domestic market so that they have a cheaper selling price. Based on data obtained from (www.indonesiainvestments.com, 2015), that tea marketing at the domestic level is not large so it is reflected in the per capita level of tea consumption in Indonesia which is still relatively low, namely the Indonesian population consumes an average of 0.32 kilograms of tea per person per day, while the world average was 0.57 kilograms in 2014.

The tea garden of Bahbutong Village, Sidamanik District, Simalungun Regency has quite a lot of workers so that more income is needed by using tea leaves to increase the economy of the village community who work in it. Tea production has also declined in recent years, as tea export prices are still below production prices. Export prices became cheap due to the global crisis which caused demand to weaken. It is recognized that there is an upward trend in prices, but it is not even below the prices of previous years. 
Table 1. Tea Plant Production in Bahbutong, Sidamanik Dalam District

\begin{tabular}{llllll}
\hline Unit & \multicolumn{5}{c}{ Production (Ton) } \\
\cline { 2 - 6 } & \multicolumn{1}{c}{2014} & 2015 & 2016 & 2017 & 2018 \\
\hline Afd I & 187.543 & 178.055 & 286.383 & 227.508 & 200.073 \\
Afd II & 202.932 & 265.440 & 331.701 & 242.684 & 215.450 \\
Afd III & 245.361 & 206.571 & 252.496 & 208.495 & 180.116 \\
Afd IV & 425.098 & 311.927 & 457.363 & 352.218 & 322.326 \\
\hline TOTAL & 1.060 .915 & 961.933 & 1.237 .943 & 1.030 .905 & 918.665 \\
\hline
\end{tabular}

Source: Bahbutong Village 2019

Based on table 1, it is known that in 2018 the production of tea plants in Bahbutong decreased by 1,030,905, while the highest production in 2016 was 1,237,943. In 2014 and 2015 tea production was also low and increased in 2016 then in 2017 and 2018 tea production fell again. This is due to the increasing number of tea plants that are old and no longer used so that the level of production is needed to increase the income of the village community. In addition, Indonesia's urban middle class is increasingly developing a "coffee consumption lifestyle"). So that the surrounding community, especially farmers, the sales of their tea gardens are down. Therefore the results in this study are the innovation of tea leaves into an aromatherapy candle to improve the community's economy as one of the community empowerment activities.

\section{DISCUSSION}

The development of resources, especially the community, is not easy, because it is related to the ability and quality to make changes. This is intended for community development related to the challenges of life to be able to survive and develop themselves in accordance with the demands of the times, one of which is empowerment. Endah (2020) argues that community empowerment essentially awakens the potential that exists in individuals or groups by providing encouragement, providing awareness of the potential possessed both individually and in groups that lead to community change that is efficient and has capabilities in socio-economic life. Then, Murdayani, et.al (2019) that empowerment is related to the ability of individuals or groups of people who are weak in gaining access to support improving the quality of productive sources so that they can increase income and participate in development activities.

Empowerment means providing resources, opportunities, vocabulary, knowledge and skills to improve people's ability to determine their own future and to participate and influence the lives of their people (Ife and Tegoriero, 2008). This understanding shows that empowerment is not just helping the poor to become not poor. The definition of empowerment according to Ife and Tesoriero is more directed at increasing the community's ability to be independent, able to control their future and even be able to influence others. Then, Suharto (2006) said empowerment refers to the ability of people, especially vulnerable and weak groups so that they have strength or ability in:

1. Meet their basic needs so that they have freedom (freedom)

2. Access productive sources that enable them to increase their income and obtain the goods and services they need, and

3. Participate in development processes and the decisions that affect them.

Community empowerment activities in Bahbutong Village are carried out with an approach that can provide solutions to existing problems, namely:

1. The main approach used in solving this problem is to process the rest of the tea plantation harvest that is no longer used into processed products which will later have economic value, namely by making tea leaf aromatherapy candles.

2. The second approach is a strategy to invite people to process tea leaves into new products so that there is public awareness to take advantage of unused tea leaves.

The approach taken in community empowerment through the use of tea leaves is also carried out by: 


\section{Extension techniques}

The counseling technique is done by providing education about tea leaves, their use can be made into any product such as tea bags, perfumes, room deodorizers, aromatherapy candles, clothing fragrances, to hair fragrances and especially aromatherapy candles. The counseling focuses on the manufacture of aromatherapy candles whose raw materials are derived from dark green tea leaves which cannot be used in making tea bags and tea leaves that are wasted due to the pruning of tea plants every year. After that, the practice of making aromatherapy candles was immediately carried out with 1 (one) person as mentoring to explain the manufacturing stages carried out by the practitioner. In delivering education, partners are given modules as teaching media that can facilitate the transfer of knowledge and the manufacture of products to be practiced.

\section{Aromatherapy Candle Training}

The training is carried out as an implementation process of the education that has been given in the extension activities. Therefore, partners who have been grouped into two groups practice directly following the guidebooks that have been given and video tutorials that have been shared and making discussions about the obstacles faced during the production of the WhatsApp group. The exercises carried out are also related to making packaging designs for selling products on social media and selling directly to tourists visiting the tea garden area around there.

\section{Sustainability Assistance}

This activity is carried out as a continuation in the production of aromatherapy candles so that they can increase the income of partners around the Jalan Kelurahan. Mentoring serves as a mentoring activity so that the implementation of community service activities does not stop after the program is completed. Mentoring activities contain activities related to product marketing and collaboration with local governments.

The benefits of tea leaves are not only for making drinks and food, but can also be processed into herbal medicines that are useful for health, including products produced in community empowerment activities in Bahbutong Village in collaboration with academics (lecturers and students) University of Muhammadiyah North Sumatera. The resulting product is tea aromatherapy candles, which can provide health benefits and realize the achievement of competitive advantage in tea leaves in the business world through the latest innovations. Aromatherapy tea leaves are seen in terms of health benefits because tea leaves contain the main alkaloids, and there are caffeine, theobromine and theofolin compounds in tea leaves that are calming or fresh when people inhale them. The goal is to improve physical, mental, and emotional health, while the aromatic plant extracts used are obtained through various processing methods and are known as essential oils.

This essential oil can help reduce anxiety by improving mood, reducing pain, nausea, fatigue or inflammation. The oil is used for smelling (inhalation) only and these smells can provide a calming effect (relaxation). Symptoms of anxiety disorders include increased panic and fear, uncontrollable obsessive thoughts, nausea, cold sweats and other uncomfortable physical reactions. Economic sessions, aromatherapy candles that utilize natural ingredients and spices can increase the economic value of using spices themselves and can be used as new opportunities to open a business. Moreover, there are many Indonesian spices that can produce essential oils, which can then be used as aromas from aromatherapy candles.

Community empowerment activities through the use of tea leaves carried out in Bahbutong Village, Sidamanik District can be considered to have gone well, based on the results of observations and assistance carried out, namely the presence of the community in this activity, as well as the enthusiasm and motivation given by the Bahbutong Village Head in supporting the community to improve understanding and ability to innovate from the potential that exists in the village. The results achieved in this activity were also carried out by Minah, et.al (2017) and Surtarna, et.al (2020), one of which was to produce aromatherapy candle products, which had the opportunity to become a home industry and UMKM to improve the community's economy. However, it is different from the materials used in community empowerment activities in 
Bahbutong village which are sourced from tea leaves. And this activity also adds to the public's insight into the use of tea leaves that are more creative, to become a product that will later have economic value and can help the economy of the village community. In addition, the sustainability to be achieved after the activity includes:

1. Become a pilot project for residents around the village

2. Increase insight and knowledge for local residents

3. Make use of tea leaves to be more varied

4. Increase income and train the entrepreneurial spirit for local residents.

The results of this community service show that there is public awareness to be able to make social changes related to the use of tea leaves in accordance with community empowerment activities launched by the village government. This is also the same as that produced by Susilo, et.al (2018) that the application of community empowerment through the 100-0-100 government program implemented in Manggar Village resulted in optimal community support for this program to carry out social changes in their village environment, so as to create a comfortable, shady and beautiful atmosphere.

\section{CONCLUSIONS AND RECOMMENDATIONS}

The counseling and training carried out in the use of tea leaves in Bahbutong Village is one of the community empowerment programs prioritized by the village government in collaboration with PTPN IV so that village communities can provide economic values that can help the village economy. This community empowerment process by processing tea leaves produces tea aromatherapy candle products that provide relaxation for health as a new innovation in tea leaf processing. This wax product is a new innovation that can provide benefits for rural communities, which aims to improve community welfare and empower village potential.

\section{ACKNOWLEDGMENTS}

We thank God for the presence of Allah Subhanahu Wa Ta'ala, for the facilities provided so that this Community Service can run smoothly. This community service can be carried out well with the support of (1) the Chancellor of the University of Muhammadiyah North Sumatra (2) the Chairperson and the SRCC Team of the Muhammadiyah University of North Sumatra (3) the Village Head of Bahbutong (4) the Community Group of the Village of Bahbutong May Allah Subhanahu Wa Ta'ala reward you with the kindness you deserve. Amen.

\section{REFERENCES}

Adimihardja, K \& H.H. (2003). Partisipatory Research Appraisal: Pengabdian dan Pemberdayaan Masyarakat. Bandung: Penerbit Humaniora

Endah, Kiki. (2020). Pemberdayaan Masyarakat: Menggali Potensi Lokal Desa. Jurnal MODERAT, Volume 6, Nomor 1, Februari 2020; ISSN 2442-3777 http://dx.doi.org/10.25157/moderat.v6i1.3319

Hamid, Hendrawati. (2018). Manajemen Pemberdayaan Masyarakat. Makassar; De La Macca

Ife, Jim \& Tegoriero, Frank. (2008). Community Development; Alternatif Pengembangan Masyarakat di Era Globalisasi. Pustaka Pelajar. Yogyakarta.

Mardikanto T dan Poersoko S. (2012). Pemberdayaan Masyarakat Dalam Perspektif Kebijakan Publik. Bandung; Alfabeta.

Minah, et.al. (2017). Pembuatan Lilin Aroma Terapi Berbasis Bahan Alami. Jurnal Industri Inovatif, Volume 7 No. 1, Edisi Maret 2017: 29 - 34 https://ejournal.itn.ac.id/index.php/industri/article/view/877/804

Murdayani, et.al (2019) Pengembangan Ekonomi Masyarakt Melalui Pemberdayaan Usaha Mikro Kecil dan Menengah (Studi di Kelurahan Kandri Kecamatan Gunungpati Kota Semarang), Jurnal Abdimas: Pengabdian Kepada Masyarakat Volume 23 (2) (2019): 152-157 DOI: http://dx.doi.org/10.15294/abdimas.v23i2.17893 
Nahruddin, Zulfan. (2014). Pemberdayaan Masyarakat Dalam Pengelolaan Hasil Perikanan di Kelurahan Sumpang Binangae Kabupaten Barru. Otoritas Jurnal IImu Pemerintahan, Volume IV No. 1 Edisi April 2014; Universitas Muhammadiyah Makassar. DOI: https://doi.org/10.26618/ojip.v4i1.83

Riyadi, dan Bratakusumah, Deddy Supriadi. 2005. Perencanaan Pembangunan Daerah (Strategi Menggali Potensi dalam Mewujudkan Otonomi Daerah). Jakarta; Gramedia Pustaka Utama Suharto, Edi. (2004). Pendekatan Pekerjaan Sosial Dalam Pemberdayaan Masyarakat Miskin: Konsep, Indikator dan Strategi. Malang.

Susilo, Ganjar. et.al. (2018) Pendampingan Pemberdayaan Masyarakat Program 100-0-100 di Kelurahan Manggar. Jurnal ABDIMAS BSI; Pengabdian Kepada Masyarakat Vol. 1 No. 2 Agustus 2018, Hal. 227-236 E-ISSN: 2614-6711 https://doi.org/10.31294/jabdimas.v1i2.3985.g2486

Sutarna, et.al (2016). Pemanfaatan Ekstrak Daun Teh Hijau (Camelia Sinensis L) Sebagai Bahan Aktif Pembuatan Sediaan Krim Tabir Surya. Kartika - Jurnal IImiah Farmasi, Desember 20164 (2), 32 -35 DOI: http://dx.doi.org/10.26874/kjif.v4i2.64

Undang-undang Nomor 6 Tahun 2014 tentag Desa

www.indonesia-investments.com, 2015 


\section{APPENDIX}

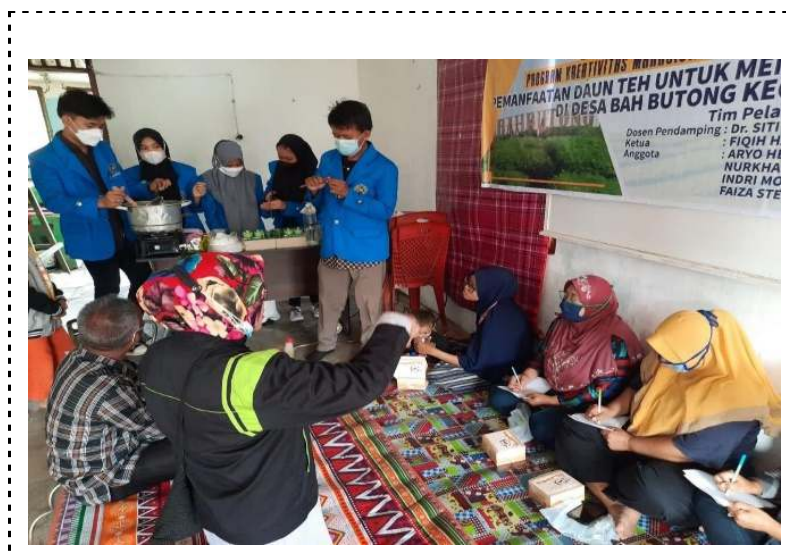

Figure 1. Implementation of Extension Activities on the Utilization of Tea Leaves

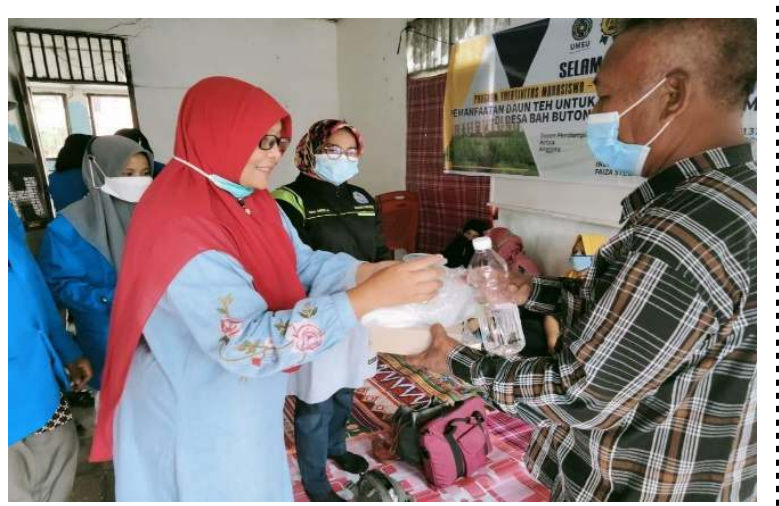

Figure 2. Implementation of PKM Mentoring Activities for the Use of Tea Leaves

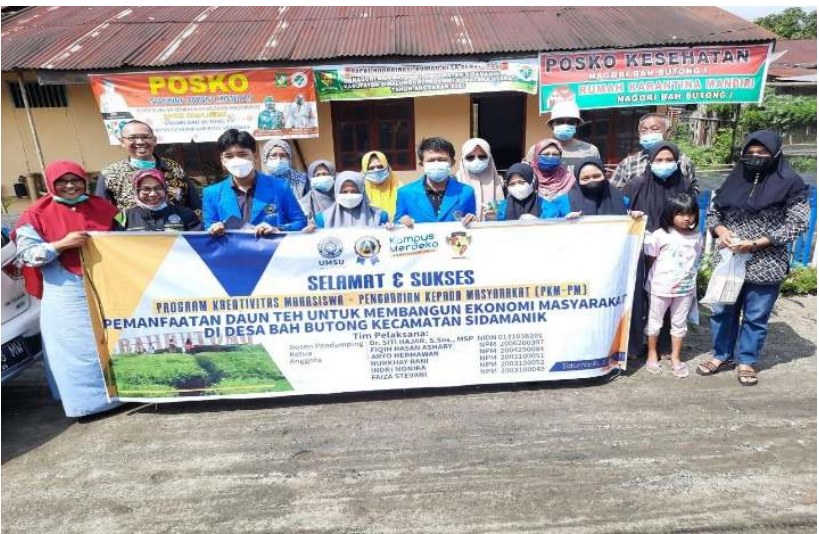

Figure 3. Evaluation of PKM Activities 